\title{
Polemics on Iconoclasm and the Predetermined Terms of Life in the Homiletical and Liturgical Works of Theodore the Studite
}

\author{
Vladimir Baranov | ORCID: 0000-0002-1218-499X \\ Junior Researcher, Novosibirsk State University of Architecture, \\ Design and Arts, Novosibirsk, Russia \\ baranovv@academ.org
}

\begin{abstract}
Although Theodore the Studite is primarily known as a monastic leader and champion of icon-veneration, he was also a prolific homilist and hymnographer. This aspect of his literary heritage is discussed from the perspective of the theological debates during the time of Theodore the Studite's life - not only the Iconoclastic Controversy which repeatedly surfaced in his writings, but also the debate on the predetermination of the terms of human life. A focus will be made on the extent the turbulent events of his life and polemics he was engaged in made an impact on his homiletical and liturgical works.
\end{abstract}

\section{Keywords}

Theodore the Studite - hymnography - homiletics - predetermined terms of life - Iconoclasm

Modern* scholars have been interested in Theodore the Studite primarily as a theologian developing an elaborate theology of image in his polemical

* This study was supported by the Russian Foundation for Basic Research (Project No. 20-011-41004 "Treatise of John Philoponus 'On the Creation of the World' in the context of 
struggle with Iconoclasm. ${ }^{1}$ Although this is a very contemporary image of a staunch fighter with ecclesiastical and civil authorities, ${ }^{2}$ this perception is largely true, and the image of Theodore the Studite in Church art steadily appears in connection with the Iconophiles, often accompanying the image of Stephen the Younger, martyred by the Iconoclasts (Fig. 1). ${ }^{3}$ This perception does not give justice to Theodore as a poet and prolific liturgical and homiletical writer whose heritage was crucial for shaping the yearly cycle of Orthodox divine services, particularly those of Great Lent, although this perception does have some grounds in the Byzantine tradition. Compared with other Byzantine Iconophile saints and liturgical poets, representations of Theodore the Studite were not usually associated with hymnographers with the notable exception of Nerezi, where Theodore appears along with Kosmas of Maiuma, John of Damascus, Theophanes Graptos, and Joseph of Sicily. In addition, this program emphasizes Theodore's monastic connection and link with the Palestinian tradition by placing his representation just across from the images of St. Euthemius the Great and St. Sabas the Sanctified (Fig. 2). ${ }^{4}$

the Middle Eastern Syrian-Palestinian and Byzantine Theological (Christological, anthropological, cosmological) Traditions."

1 Some recent studies include O. Y. Goncharko and D. N. Goncharko, "A Byzantine Logician's 'Image' within the Second Iconoclastic Controversy. Theodore the Studite," Scr, 15 (2019), pp. 163-177; B. Lourié, "Theodore the Studite's Christology Against Its Logical Background," Studia humana 8 (1) (2019), pp. 99-113; T. Tollefsen, St. Theodore the Studite's Defence of the Icons: Theology and Philosophy in Ninth-Century Byzantium (oEcs), Oxford, 2018; D. Krausmüller, "On the Relation between the Late Antique and Byzantine Christological Discourses: Observations about Theodore the Stoudite's Third Antirrheticus," Jӧв, 68 (2) (2018), pp. 239-250; K. Parry, “Theodore_the_Stoudite: The Most 'Original' Iconophile?” JöB, 68 (2018), pp. 261-275.

2 A. Stambolov, "Monks vs. the State: The Stoudites and Their Relations with the State and Ecclesiastical Authorities in Late Eighth and Early Ninth Century Byzantium," Annual of Medieval Studies at CEU, 21 (2015), pp. 193-205.

3 Skopje, Matka Church of St. Andrew, the church of St. Nicetas the Goth at Čučer, the parecclesion of St. Nicholas in the monastery church of the Theotokos at Gračanica, Katholikon of Hosios Lukas and Nea Moni Hagia Sophia in Thessaloniki. In the narthex of the Boyana Church, Theodore is depicted among the monastic saints.

4 See O. Ovcharova, "Images of the Holy Hymnographers in the Iconographical Programme of the Church of St Panteleemon in Nerezi, Macedonia (1164)," Al-Masaq: Islam and the Medieval Mediterranean 16 (1) (2004), pp. 131-146, p. 142. See also Г. Бабић [G. Babich], Краљева ирква у Студениии [King's church in Studenitsa], Belgrade, 1987, p. 166; Е. Бакалова, Ц. Василев [E. Bakalova, T. Vasilev], “Образите на св. Теодор Студит в България и техният балкански контекст" [Images of St. Theodore the Studite in Bulgaria and their Balkan context], in: Герои, Култове, Светии [Heroes, Cults, Saints], eds. И. Гергова, Е. Мутафов [I. Gergova, 


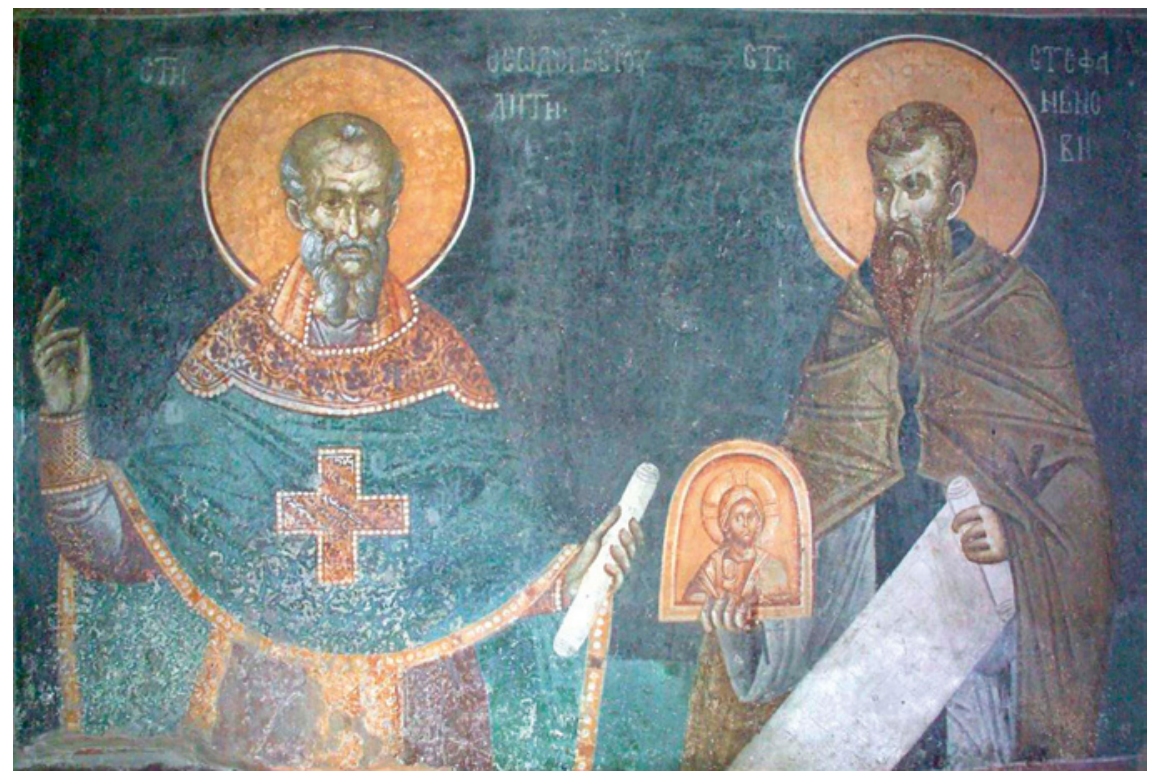

FIGURE 1 Theodore the Studite and Stephen the Younger, southern wall in the Parecclesion of St. Nicholas in the monastery church of the Theotokos, Gračanica. 14th C

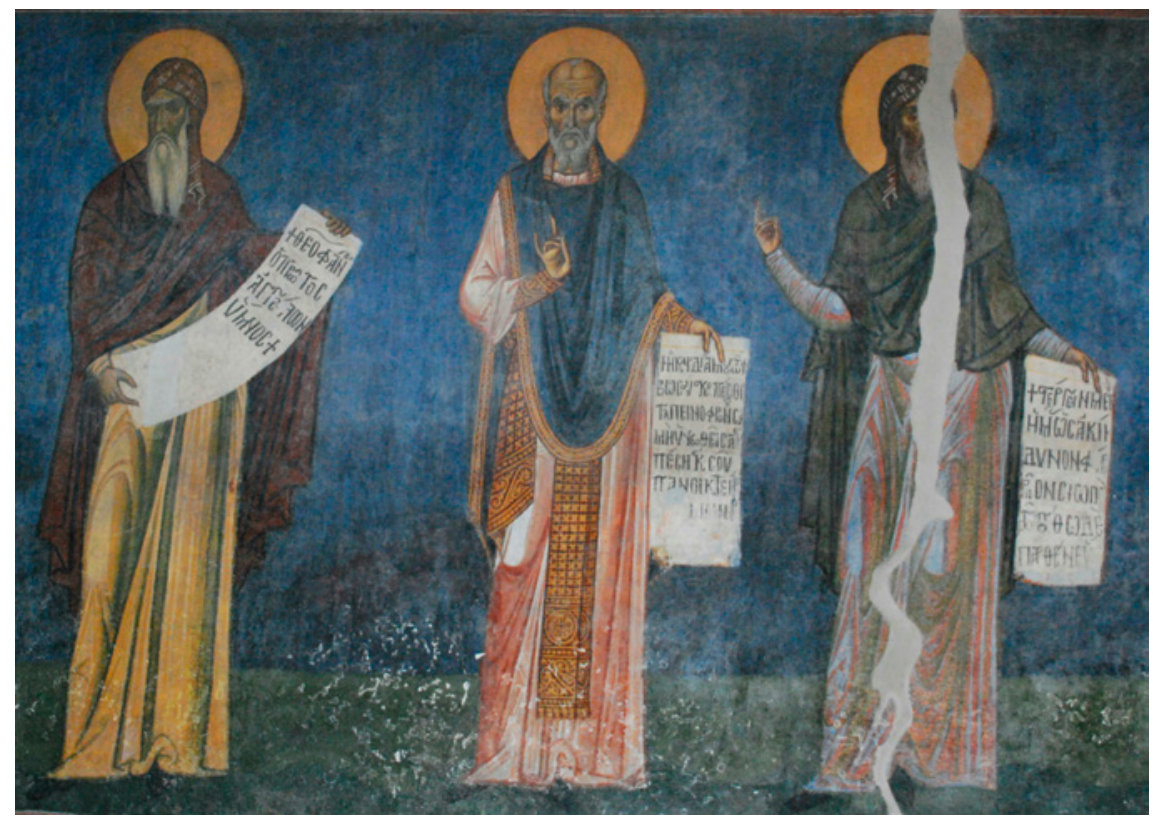

FIGURE 2 Holy Hymnographers, north wall, Church of St. Panteleimon, Nerezi, the 116 os 
A miracle from the Life of Theodore the Studite mentions wide circulation of the hymnographic heritage of St. Theodore in various monastic circles in the early period, initial ambiguity of its adoption, and finally its divinely inspired sanctioning. ${ }^{5}$ The Life says that the Bishop of Sardinia procured the Triodia of Great Lent composed by Theodore the Studite and used to chant them during Lent. One day some monks who visited the Bishop learned about this habit, were scandalized, started to ridicule St. Theodore and his hymns, and dissuaded the Bishop from doing so for the reason that the Triodia were composed "not according to the rules." The next night St. Theodore and accom-

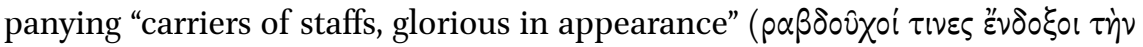

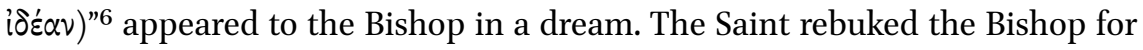
receiving bad monks and leaving his good habit, and ordered his companions to give a harsh beating to the Bishop, leaving marks on his body which remained after he woke up.

This study will attempt to unite the images of St. Theodore as hymnographer, polemicist, and monastic leader, looking at the contents of some of his homiletical and liturgical writings from the viewpoint of the theological controversies in which Theodore was engaged in his lifetime. This task is complicated by several methodological problems. The first and common problem with Byzantine texts is associated with the understudied manuscript tradition and textology of Theodore's liturgical canons and homilies. The second problem is associated with the genres. Although, as A. Nikiforova aptly noted concerning the hymnographical heritage of Patriarch Germanus of Constantinople that his canons were "rhythmisized sermons,"7 and this observation is certainly applicable to the hymnographical works of Theodore the Studite, the latter's homilies were more instructive in nature and would more often address issues from current life, not only contextualizing the feast, giving its typological meaning and Scriptural exegesis, but also equipping the listeners with instructions on doctrinal problems of the time or even correct responses to pressing political issues. Since Canons are incorporated into the cycle of the yearly divine service, their vector is directed somewhat differently:

E. Mutafov], Sophia, 2015, pp. 145-163; D. Mouriki, "The Portraits of Theodore Studites in Byzantine Art," Jahrbuch der Österreichischen Byzantinistik, 20 (1971), pp. 249-280.

5 Vita B, PG 99, 312 C-313 B. On the relationship between the recensions of the Vita, see D. Krausmüller, "The Vitae $B, C$ and $A$ of Theodore the Stoudite: Their Interrelation, Dates, Authors and Significance for the History of the Stoudios Monastery in the Tenth Century," Analecta Bollandiana, 131 (2013), pp. 280-298.

$6 P G$ 99, 313 A.

7 А. Ю. Никифорова [А. Y. Nikiforova], "Неизвестное гимнографическое наследие константинопольского патриарха Германа" [Unknown hymnographic heritage of Patriarch Germanus of Constantinople], Вестник ПСТГУ III: Филология [Herald of Saint Tikhon's Orthodox University III: Philology], 4 (26) (2011), pp. 29-43 at p. 37. 
they tend to address the ultimately transitory past and present only to juxtapose them with the ontologically more real and eternal heavenly liturgy. The Homilies of Theodore the Studite were primarily intended for theological and moral instruction, whereas the Canons were intended for prayerful enactment of sacred history.

This difference can be illustrated by comparing the Canon and Homily of Theodore the Studite on the same subject: the Cross - and for the same feast day of the Sunday of the Adoration of the Holy Cross, marking the middle of Great Lent. Both are based on previously existing works, such as the Easter Canon of John of Damascus, from which Theodore borrowed the Irmoi as models of the corresponding Troparia of each Ode, giving his canon a recognizably Damascenian and distinctively Paschal tenor, and one of the pseudoChrysostomian homilies on the Cross (CPG 4672). ${ }^{8}$ In this Homily, the Cross reveals Christ who, in turn, manifests the invisible Father:

Let us venerate and praise in hymns the revered and thrice-blessed wood of the Lord. "The light of Thy countenance has been marked as a sign upon us!" (Ps. 4:7). What then is the light if not the Cross of our Lord and God and Savior Jesus Christ through whom [or through which, the Cross - V. B.] the world has been saved and the believers have been freed from the captivity of Belial and the list of our transgressions has been torn. The Face of the Father is Christ: "The one who has seen me," he says, "has seen the Father" (Jn. 14:9). The light of the Lord's Face, that is the Cross. ${ }^{9}$

The attribution of the Canon on the Sunday of the Cross to Theodore the Studite can be confirmed comparing the Canon with the Homily on the Holy Cross by the same author. ${ }^{10}$ The Second Troparion of the Eighth Ode of the Canon seems to allude both to Theodore's Homily and the Pseudo-Chrysostomian Homily:11

8 In adoratione venerandae crucis ( $\mathrm{PG} 62,747-754$ ). On the textological tradition of the Homily, see S. J. Voicu, "Fonti dell'omelia pseudocrisostomica 'In adorationem uenerandae crucis' (PG 62, 747-754; BHG 415; CPG 4672)," OCP, 58 (1992), pp. 279-283.

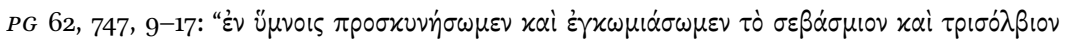

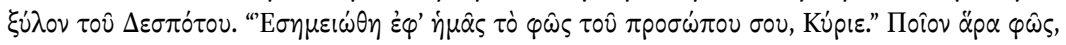

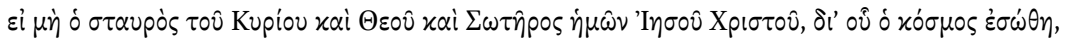

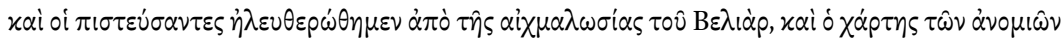

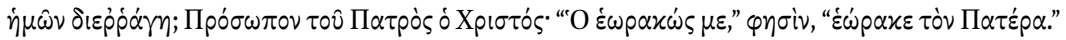

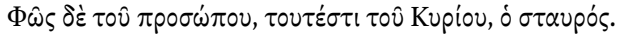

$10 \quad P G 99,692 \mathrm{~B}-700 \mathrm{C}$.

11 The offices dedicated to the Cross in the rite of Byzantine Church are described in J. Hallet, "La Croix dans la rite Byzantin. Histoire et Théologie," Parole de l'Orient, 3 (1972), pp. 261-311. 
Rejoice, the thrice-blessed and divine Wood, the Cross, Light for those in darkness, enlightening the world within the four boundaries showing through you the rays of Christ's Resurrection. Make all the faithful worthy to approach Easter! ${ }^{12}$

This tradition visually appears in the post-Iconoclastic marginal Psalters, where the illustration to the Psalmic verse "O Lord, the light of Thy countenance has been marked as a sign upon us!" (Ps. 4:7) cited in the pseudo-Chrysostomian Homily, is illustrated by David standing before the Cross which has a medallion representing the face of Christ in the middle (Fig. 3), accompanied by the

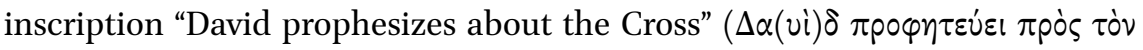

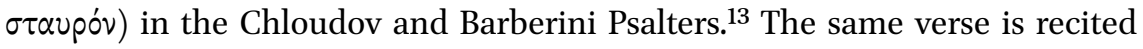
as the Communion Verse (Koinonikon) in the Liturgy of both the Feast of Exaltation of the Cross and the Sunday of the Adoration of the Cross on the third week of Great Lent in the Orthodox Church. ${ }^{14}$ The first Stichira at the Litia of the Vespers on the Feast of Exaltation of the Cross, attributed to St. Andrew of Crete, follows the same exegetical tradition:

Today the holy saying of David truly has come to pass, for behold, in the sight of all, we venerate the footstool of Thy undefiled feet, and, putting our hope in the shadow of Thy wings, we cry aloud to Thee, $\mathrm{O}$

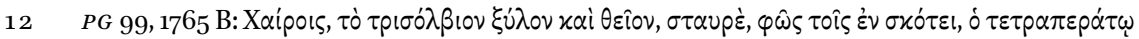

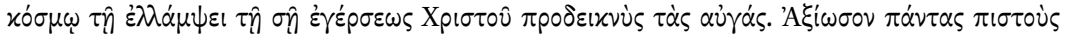

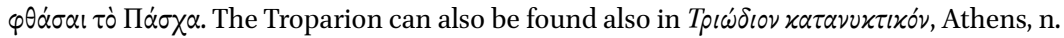
d., p. 235 with minor differences.

13 Chloudov Psalter, f. 4r.; London Psalter, f. 3v; Barberini Psalter, f. 9v; see C. Walter, "Christological Themes in the Byzantine Marginal Psalters from the Ninth to the Eleventh Century," REB, 44 (1986), pp. 269-287 at pp. 279-28o); on various aspects of marginal Psalters, see C. Walter, "Latter-day' Saints and the Image of Christ in the Ninth Century Byzantine Marginal Psalters," REB, 45 (1987), pp. 205-222; K. Corrigan, Visual Polemics in the Ninth-Century Byzantine Psalters, Cambridge, 1992; M. Evangelatou, The Illustration of the Ninth-Century Byzantine Marginal Psalters: Layers of Meaning and Their Sources, Doctoral Dissertation, Courtauld Institute of Art, University of London, 2002; Eadem., "Liturgy and the Illustration of the Ninth-Century Marginal Psalters," DOP, 63 (2009), pp. 59-116; M. Meyer, "The Personification of Zion in Byzantine Psalters with Marginal Illustrations: Between Eschatological Hopes and Realia," Ars Judaica, 5 (2009), pp. 7-22; E. Maayan, "Silenus among the Jews? Anti-Jewish Polemics in Ninth-Century Byzantine Marginal Psalters," in Between Judaism and Christianity: Art Historical Essays in Honor of Elisheva (Elisabeth) Revel-Neher, eds. K. Kogman-Appel and M. Meyer (The Medieval Mediterranean, 81), Leiden, 2008, pp. 259-280; И. А. Орецкая [I. A. Oretskaya], "Еще несколько замечаний по поводу византийских псалтирей IX века" [Some more remarks concerning Byzantine Psalters of the ninth century], Византийский Временник [Byzantine Chronicle], 61 (86) (2002), pp. 151-171.

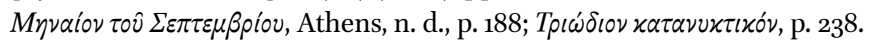




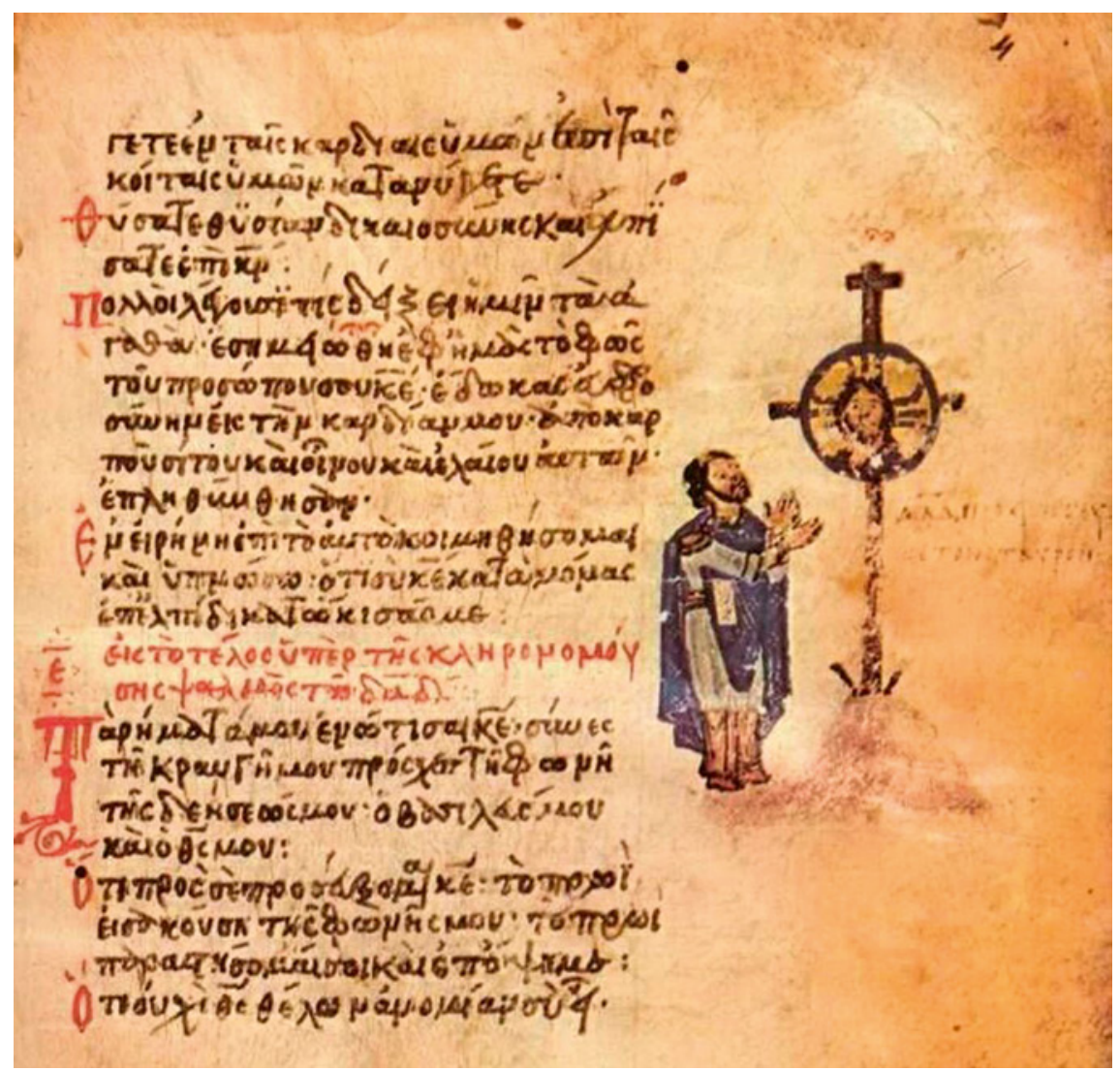

FIGURE 3 David standing in front of the Cross, Chloudov Psalter, fol. 4r, mid 9th C (after М. Щепкина [M. Shchepkina], Миниатюры Хлудовской псалтири. Греческий иллюстрированный кодекс IX века [Miniatures of the Khludov Psalter. Greek illuminated codex of the ninth century], Moscow, 1977)

all-compassionate Lord: "May the light of Thy countenance be marked as a sign upon us!" Exalt the horn of Thine Orthodox people by the Exaltation of Thy precious Cross, O Christ of many mercies! ${ }^{15}$

The Homily on the Adoration of the Cross of Theodore the Studite shows parallels with his Canon and the pseudo-Chrysostomian Homily:

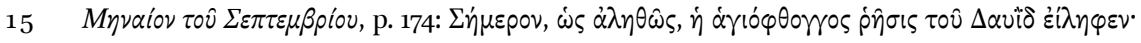

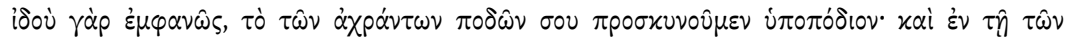

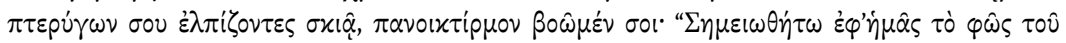

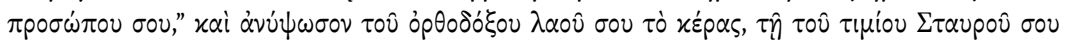

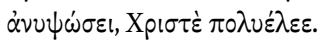


Homily of Theodore the Studite

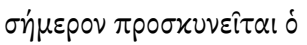

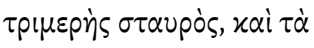

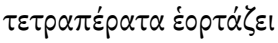

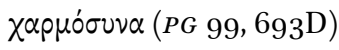

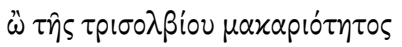

(PG 99, 696B)

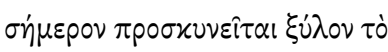

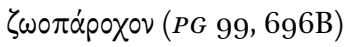

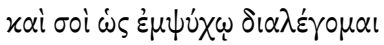

(PG 99, 70०B)

$\dot{\eta} \tau \hat{\omega} \nu \tau 0 \hat{\mathrm{M}} \mathrm{M} \omega \sigma \varepsilon \dot{\varepsilon} \omega \varsigma \chi \varepsilon เ \rho \hat{\omega} \nu$

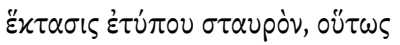

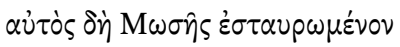

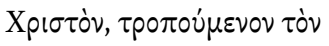

¿óp $\alpha \tau o v$ 'A $\mu \alpha \lambda \dot{\eta} x$

(PG 99, 697B)

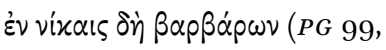
$697 \mathrm{~B})$

\section{Homily of pseudo- \\ Chrysostom}

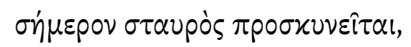

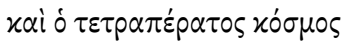

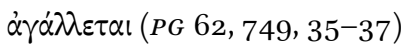

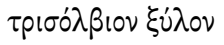

(PG 62, 747, 6-7)

$\tau \rho เ \sigma o ́ \lambda \beta เ \varepsilon \sigma \tau \alpha \cup \rho \dot{~}$

(PG 62, 753,7)

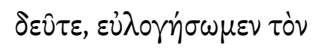

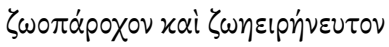

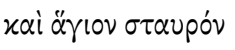

(PG 62, 751, 11-13)

\section{Canon of Theodore \\ the Studite}

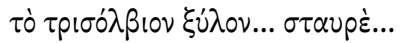

ó $\tau \varepsilon \tau \rho \alpha \varepsilon \varepsilon \rho \dot{\alpha} \tau \omega$ xó $\sigma \mu \omega \tau \hat{\imath}$

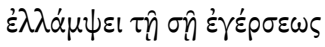

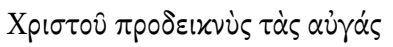

(Ode 8, a Troparion 2, PG 99, $1765 \mathrm{~B})$

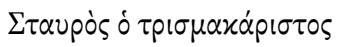

(Ode 4, Troparion 3, PG 99, $1760 \mathrm{C}$ )

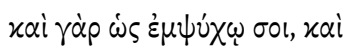

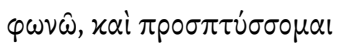
(Ode 1, Troparion 3, PG 99, 1757 B)

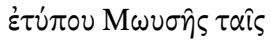

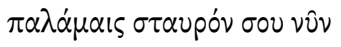

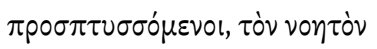

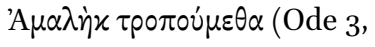
Troparion 3, $P G$ 99, 176oA)

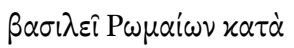

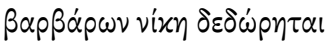

(PG 62, 749, 32-34)

a According to the structure of the Orthodox liturgical canon, it has nine odes, and the second ode is often omitted, as is the case with this canon. The Patrologia Graeca, however, gives a continuous numeration to the eight odes of the canon. The numeration here will be in the traditional manner with the omission of the second ode and will differ from that in $P G$.

Both Theodore's Canon and Homily on the Cross refer to the same standard Scriptural passages and events from sacred history, such as Moses raising his 
arms to defeat Amalek ${ }^{16}$ or Elisha placing wood into the water, ${ }^{17}$ and apply the same descriptions and epithets such as the three-partite Cross enlightening the four ends of the world ${ }^{18}$ both address the feast as an announcement of the Resurrection..$^{19}$ However, the canon marks the milestone of Great Lent, announcing the forthcoming Passion Week ${ }^{20}$ and Easter in terms of the calendar, and celebrating the Cross as a tool of Christ's sacrifice and Resurrection. Every feast is essentially a gathering of the heavenly and earthly churches for the same festal celebration here and now, ${ }^{21}$ as well as a reminder of the prefigurations of the event in sacred history, events from world history, and their fulfillment (the Cross of Golgotha as the new Tree of Paradise, and eschatological paradise of the saints). There is simply no place for Iconoclasts in the reality of the Canon, since the festal service is a calendric image of timeless heavenly service, whereas the Homily contains an important section, providing the listeners with counterarguments against the Iconoclasts and preserving a valuable testimony to the Iconoclastic doctrine of the Cross:

You see, my friend, what power is in the typos of the Cross! If it is so, then it is also in the typos of the crucified Christ: for surely, inasmuch as the prototypes are more perfect, the copies are also more useful. And what if anybody asks: "I want to know: who prefigured the typos of Christ in the ancient times?" - Those, I say, who prefigured the Cross: for as the stretching of Moses' hands was the image of the Cross, thus also Moses himself prefigured Christ crucified, defeating the invisible Amalek, and the same can be understood with other examples when one is revealed by the typos of the other. "But that one," - you say, - "was an animated typos. Then why do you speak about the soulless one?"22 As with the

16 Ode 3, Troparion 3, PG 99, 176o A / PG 99, $696 \mathrm{D}$ and $698 \mathrm{~B}$ (canon/homily).

17 Ode 8, Troparion 4, $P G$ 99, 1765 B / PG 99, 697 A (canon/homily).

18 Ode 8, Troparion 2, PG 99, 1765 B / PG 99, $693 \mathrm{D}$ (canon/homily).

19 Ode 1, Troparion 2, PG 99, 1757 B / PG 99, 693 C (canon/homily).

20 Ode 4, Troparion 2, $P G$ 99, 176o C.

21 Cf. Theodore the Studite, Homily on the Cross, PG 99, 693B; Homily on the Synaxis of the Heavenly Ranks, $P G$ 99, 729 C.

22 A similar doctrine is contained in an Iconoclastic verse by Sergius from the collection of Iconoclastic inscriptions refuted by St. Theodore the Studite (PG 99, $437 \mathrm{~A}$, trans. S. Gero, Byzantine Iconoclasm during the Reign of Leo III with Particular Attention to the Oriental Sources (cSCO, Sub. 41), Louvain, 1973, p. 122): "Moses destroyed the principalities manifestly by this sign, and prevailed over the enemy. Now the Cross, the glory of the faithful, stemmed the mighty current of deceit. The image of artifice, devoid of life, which was 
typos of the Cross - when a visible yet soulless thing makes a miracle, [then] as with the Cross-like image, the Christ-like image makes miracles in the animated and soulless, as having in itself the shape and form of the archetype and by this appropriating the same honor and veneration, as well as the name - this is obvious. [...] For whoever destroys the image, also destroys the very prototype, because these two have similarity between themselves and relation in the eyes of those who are of sound mind. ${ }^{23}$

Considering the crucial role of Christ' soul as the mediator between the divinity and material flesh in the Iconoclastic doctrine, ${ }^{24}$ this passage from Theodore's Homily may indicate that according to the Iconoclasts, the typos of the Cross was to be understood as a succinct image of the animated figure of Christ on the Cross with his hands stretched apart, which had a long iconographical tradition before and during Iconoclasm (Fig. 4), ${ }^{25}$ and also the Cross as the non-anthropomorphic representation of the Resurrected, glorified, and undepictable Christ. ${ }^{26}$

Theodore also includes brief sections on Iconoclasm concerning the spatial circumscription of the Lord according to the flesh ${ }^{27}$ in his Homily on the Eve of Theophany, ${ }^{28}$ mentions the icons of the Theotokos which were left for our veneration here on Earth after her Dormition and Ascension in the Homily on

pictured here, devised as a hidden weapon by an illicit impulse, was completely taken away. Those who know Christ should think in this manner."

$23 \quad P G$ 99, 697 BC.

24 V. A. Baranov, "Origen and the Iconoclastic Controversy," in: Origeniana Octava. Origen and the Alexandrian Tradition, ed. L. L. Perrone, vol. 2 (BETL, 164), Leuven, Peeters, 2003, pp. 1043-1052, and V. A. Baranov, and B. Lourie, "The Role of Christ's Soul-Mediator in the Iconoclastic Christology," in Origeniana Nona. Origen and the Religious Practice of His Time, eds. G. Heidl and R. Somos (BETL, 228), Leuven, 2009, pp. 4O3-411.

25 On the change in the iconography of the Crucifixion, representing Christ dead on the Cross, after Iconoclasm, see J. R. Martin, "The Dead Christ on the Cross in Byzantine Art," in: Late Classical and Medieval Studies in Honor of A. M. Friend, Jr., ed. E. Kitzinger, Princeton, NJ, 1955, pp. 189-196.

26 In more detail, see V. A. Baranov, "Instrument of Death and Tree of Life. Visual Meanings of the Cross in Some Late Antique and Byzantine Monumental Programs," Scr, 11 (2015), pp. 22-48, esp. pp. 44-47.

27 On the argument of circumscribability in Theodore the Studite, see C. Erismann, "To Be Circumscribed Belongs to the Essence of Man': Theodore of Stoudios on Individuality, Circumscription and Corporeality," Jahrbuch der Österreichischen Byzantinistik, 68 (2018), pp. $225^{-238 .}$

$28 \quad P G$ 99, $704 \mathrm{~B}, 705 \mathrm{C}$. 


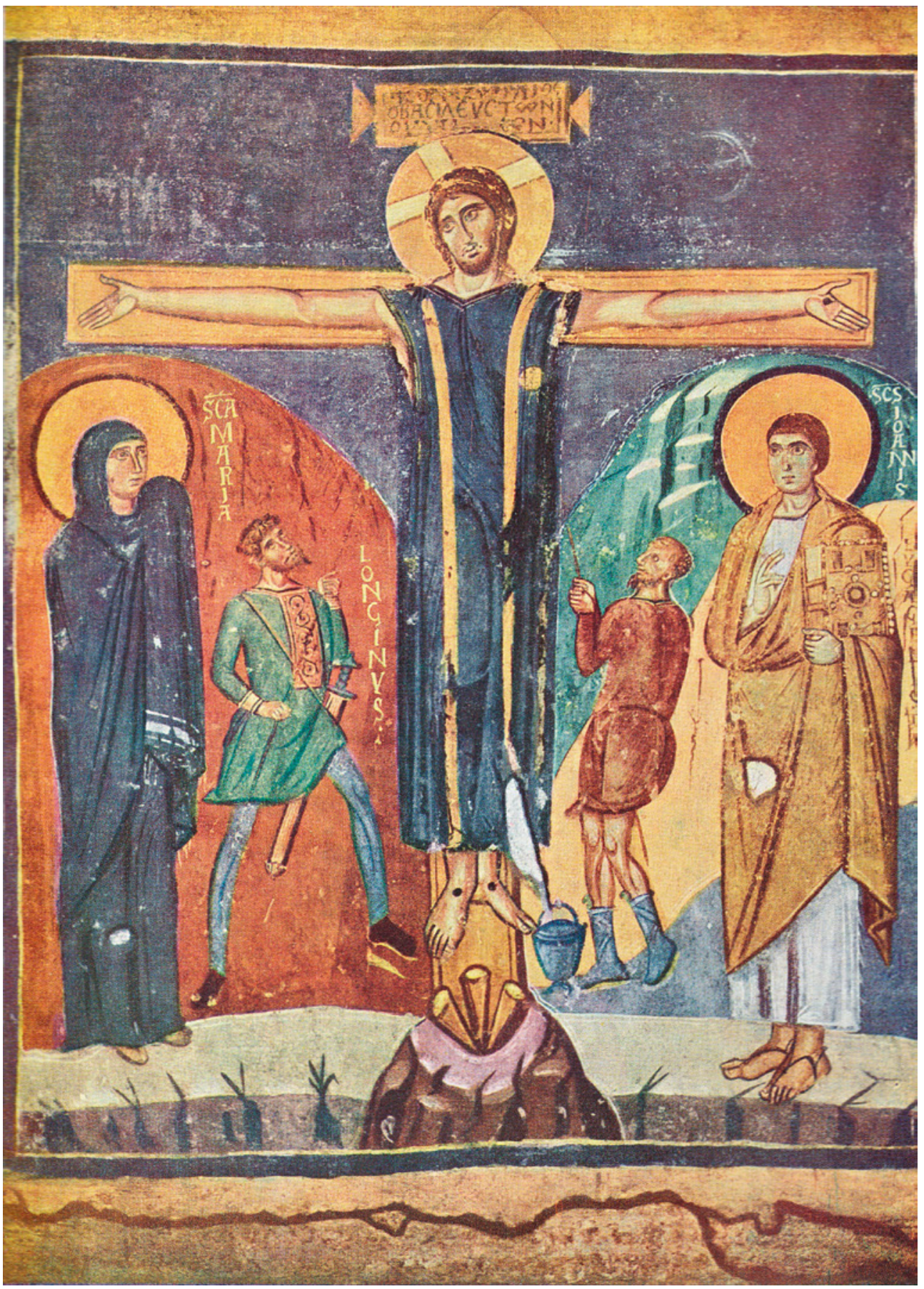

FIgure 4 Crucifixion, fresco, Santa Maria Antiqua, Rome, 741-752 
Dormition, ${ }^{29}$ justifies the validity of representing Christ on the basis of angelic visions in the Homily on the Birth of John the Baptist,$^{30}$ praises the veneration of relics, ${ }^{31}$ rebukes the unlawful marriage of the Emperor Constantine VI in the Homily on the Beheading of John the Baptist, ${ }^{32}$ and addresses with a concluding prayer to put an end to the Iconoclastic turmoil in the Homily to the Apostle John. ${ }^{33}$

However, there is one notable example of Theodore's canons which seems to be a clear response to the theological discussions of his time. It is the Canon of the Saturday of Meat-fare Week commemorating the dead, which is very unusual in its contents. The Canon is essentially a catalog of all kinds of "untimely" deaths which might put an end to human life: the canon mentions those who were frozen to death, drowned, murdered, have died in war or from wounds, were struck by lightning, fallen bricks, stones or soil, died from a blizzard, earthquake, fire, sword, horse or snake, or were strangled.

Theodore places this enumeration in a proper theological context in the first Odes: the time and manner of these terrible and seemingly "untimely" deaths were in fact fixed by God, Who "predetermined the end of each person's life, its term and manner,"34 "gave limits to our lives," 35 and "established the terms of life by righteous judgment"36 for those whom He "predetermined in the palm of His hand."37 However, this was not simply a theoretical theological construct embedded into liturgical poetry, but a poetical and liturgical way of expressing Theodore's own views on the predetermined terms of human life.

$29 P G 99,721$ B.

$30 \quad P G 99,75^{2} \mathrm{CD}$.

$31 \quad P G$ 99, 76 в вс.

$32 \quad P G 99,769 \mathrm{C}$.

$33 \quad P G$ 99, 788 вС.

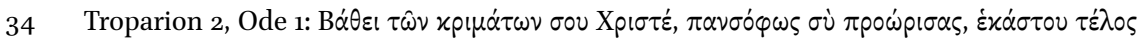

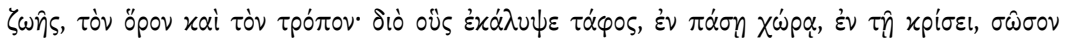

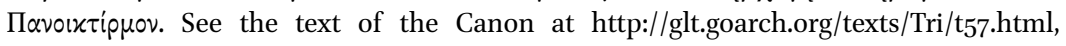
accessed November 1, 2020; the English translation is available in The Lenten Triodion, transl. Mother Mary and Archimandrite Kallistos Ware (The Service Books of the Orthodox Church), South Canaan, PA, 2002, pp. 129-138.

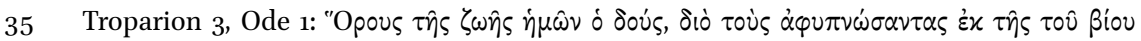

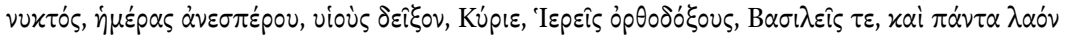
боบ.

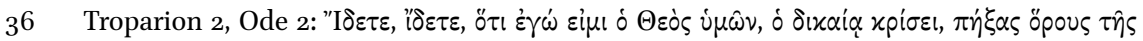

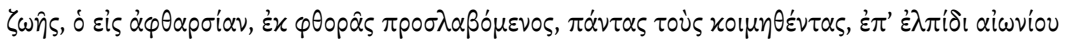
$\dot{\alpha} \alpha \sigma \tau \alpha \dot{\alpha} \sigma \varepsilon \omega \varsigma$.

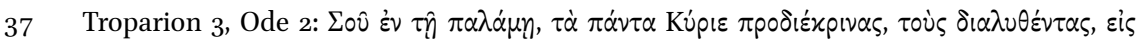

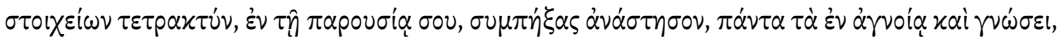

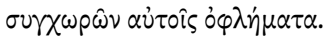


Debate on predetermined or changeable terms of human lives as a basic problem of human religious consciousness accompanied the entire history of Byzantine Christianity. However, its scope shifted from refuting the errors of Greek philosophers regarding divine providence in the earlier periods, to inner Christian problems of theodicy, efficacy of the intercessory prayers of saints, and harmonization of Scriptural passages containing diverging views on the subject in the later periods. The discussion of providence and predetermination continued in the writings of Maximus the Confessor, ${ }^{38}$ Anastasius of Sinai, ${ }^{39}$ Patriarch Germanus, ${ }^{40}$ John of Damascus, ${ }^{41}$ and in a number of hagiographical writings.

In his recent article, Dirk Krausmüller gathered ample evidence on intensification of the debate on the fixed or changeable terms of life from the second half of the seventh century. ${ }^{42}$ The issue of fixable or flexible terms of life was not only a problem faced by any believing Christian, especially during times of turmoil and instability, but was also tacitly related to the problem of the efficacy of prayers of intercession as a means of averting an untimely death and granting a "Christian end to life, peaceful, without shame and suffering, and a good account before the fearful judgment throne of Christ." ${ }^{33}$ Discussing the

38 G. Benevich, "Maximus Confessor's Teaching on God's Providence," in: The Architecture of the Cosmos: St Maximus the Confessor. New Perspectives, eds. A. Lévy, P. Annala, O. Hallamaa, and T. Lankila with the collaboration of D. Kaley, Helsinki, 2015, pp. 130-139; K, Parry, "Fate, Free Choice and Divine Providence," in: The Cambridge Intellectual History of Byzantium, eds. A. Kaldellis and N. Siniossoglou, Cambridge, 2017, pp. 350-355.

39 J. A. Munitiz, "The Predetermination of Death: The Contribution of Anastasios of Sinai and Nikephoros Blemmydes to a Perennial Byzantine Problem," DOP, 55 (2001), pp. 9-2O.

40 Germanos. On Predestined Terms of Life, ed. and trans. C. Garton and L. G. Westerink (Arethusa Monographs, 7), Buffalo, NY, 1979.

41 John of Damascus, Dialogus contra Manichaeos, ed. B. Kotter, Opera polemica, Die Schriften des Johannes von Damaskos IV (PTS, 22), Berlin - New York, 1981, pp. 351-398; Expositio fidei, II, 28-30, ed. B. Kotter, Expositio fidei, Die Schriften des Johannes von Damaskos II (PTS, 12), Berlin - New York, 1973, pp. 99-106; see also V. A. Baranov, "Human Destiny and Divine Providence in Two Byzantine Authors of the Early Eighth Century," Scr, 15 (2019), pp. 3-29.

42 D. Krausmüller, "Affirming Divine Providence and Limiting the Powers of Saints: The Byzantine Debate about the Term of Life (6th-11th Centuries)," Scr, 14 (2018), pp. 392-433.

43 Krausmüller, "Affirming Divine Providence," pp.402-406. For the background of the debate on predetermined terms of life, see $H$. Beck, Vorsehung und Vorherbestimmung in der theologischen Literatur der Byzantiner (OcA, 114), Rome, 1937, M. Levering, Predestination. Biblical and Theological Paths, Oxford, 2011 and Г. И. Беневич [G. I. Benevich], Краткая история «промысла» от Платона до Максима Исповедника [Brief history of "providence" from Plato to Maximus the Confessor], St. Petersburg, 2013; K. Parry, "Fate, Free Choice and Divine Providence," pp. 341-36o; see the review of this chapter by G. I. Benevich in Scr, 14 (2018), pp. 514-518; K. Parry, "Providence, Resurrection, and 
development of the debate in the ninth century, D. Krausmüller gave ample evidence that Theodore the Studite was an "unequivocal defender of a fixed term of life," ${ }^{44}$ using the evidence of his catecheses, hymn on the funeral of a monk, and letters.

When we read the Letters of Theodore the Studite, it becomes clear that death was the most frequent and most discussed issue there. Many times Theodore mentions his own frequent near-death experiences in the troubles of exile (Letter 3 to Plato, ${ }^{45}$ Letter $302^{46}$ and $410^{47}$ to the brethren, Letter 441 to Hypatius, ${ }^{48} 415$ to Naucratius ${ }^{49}$ ), laments on the deaths of his friends, spiritual brothers and fathers, and relatives (Letter 533 to Peter, Bishop of Nicaea, ${ }^{50}$ 114 to Athanasius, ${ }^{51} 458$ to Euphrosynia, ${ }^{52} 311$ to Anatoly, ${ }^{53} 211$ to the sisters Irene and $\mathrm{Kali}^{54}$ ), and gives numerous consolations to his spiritual children on the deaths of their beloved ones ( 398 to Basil the Patrician, ${ }^{55} 420$ to Stephan the Magister, ${ }^{56} 454$ to the widow Democharia, ${ }^{57} 498$ to the wife of the Greek turmarchos, ${ }^{58}{ }^{22}$ to the spatharia, the wife of Flavian, ${ }^{59}$ or Letter 18 to Staurakius the Spatharius) ${ }^{60}$ or Letter 29 to Leo the Orphanotrophos and his wife on the death of their third child, which can be quoted as an example here:

Restoration in Byzantine Thought, Eighth to Ninth Centuries," Studia Patristica, 97 (23) (2017), pp. 295-304.

44 Krausmüller, "Affirming Divine Providence," pp. 417-419.

45 Ed. G. Fatouros, Theodori Studitae Epistulae, vol. 1, Berlin, 1992, (CFHB, 31) [hereafter Fatouros, page, line]), pp. 13.70-14.75.

46 Fatouros, vol. 2, p. 444.1-19.

47 Fatouros, vol. 2, p. 571.38-42.

48 Fatouros, vol. 2, pp. 620-622.

49 Fatouros, vol. 2, p. 578.1-18.

$50 \quad$ Fatouros, vol. 2, pp. 804-8o6.

51 Fatouros, vol. 2, p. 233. The ending of this letter (p. 233.20-25) contains a succinct formulation of St. Theodore's view on death and divine providence: “... only one death is fatal - sinful death; and that it is not the place of death to be inquired about, but the mode of death. I thanked the Lord for what happened, leaving everything to the inscrutable judgments of His Providence - even before the creation of the world, He assigned each

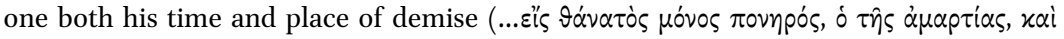

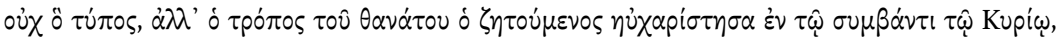

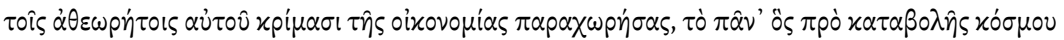

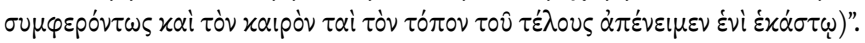

$52 \quad$ Fatouros, vol. 2, pp. 651-653.

53 Fatouros, vol. 2, p. 454.12-20.

54 Fatouros, vol. 2, pp. 333-334.

55 Fatouros, vol. 2, pp. 553.17-554.45.

56 Fatouros, vol. 2, p. 588.10-18.

57 Fatouros, vol. 2, pp. 643-644.

58 Fatouros, vol. 2, pp. 734-737.

59 Fatouros, vol. 2, pp. 777-779.

6o Fatouros, vol. 1, pp. 49-5o. 
And the pain will be soothed not by a speech, not by a consolation, not by a human being, not by an angel, but by God alone who has thus fixed the term of our life, for he it is, my lord, who took your thrice-beloved child, as he had already taken the ones before. ${ }^{61}$

Theodore's belief in the righteous and most-wise God, predetermining the time and way to take the soul of a person in the best moment for the eternal destiny of the person could have indeed emerged on the basis of previous thinkers - proponents of predetermination, such as Maximus the Confessor or Germanus of Constantinople. Nevertheless, this was in no way a universally established ecclesiastical doctrine at his time, ${ }^{62}$ but his deep and personal conviction. Thus, in a Letter to his mother, responding to the news about her grave illness Theodore writes with deep affection about his fear of her death:

If it were possible to send tears in letters, I would fill this letter with them and send them to you in these days, my respectable, sweet and godly mother. Really, I cannot bear to hear about you - I am not talking about being close to the grave, but also about diseases threatening with death ... How, mother, can I continue to write the letter without tears? Is it really my destiny in my wretched life to hear about your death, sing lamenting songs to you, see your coffin and write funeral elegies so that you could rest with your body underground, for I know that you will dwell in heaven with your spirit - while I will remain on earth continuing to lead my life full of pains and sins?

How can one bear this? May this not be with me! However, everything must be left to the will and determination of our Most-Benevolent God. For He knows what is good for each of us, knows what is needed, arranges what is needed. He is a child-loving Father, He disposes of everything well, sagaciously, providentially, most-wisely, in the most-perfect and incomprehensible [the variant reading is preferred here - V. B.] way. $\mathrm{O}$ wisdom and depth of His judgments, "for His ways are unsearchable, and inscrutable" (Rom. 11:33)! ${ }^{63}$

61 Transl. Krausmüller, "Affirming Divine Providence," p. 418 of Fatouros, vol. 1, p. 81.19-23:

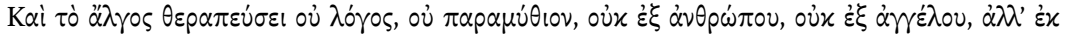

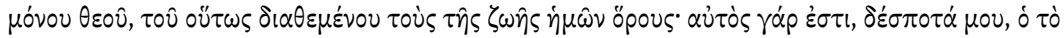

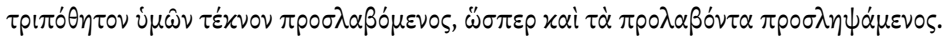

62 Krausmüller, "Affirming Divine Providence," p. 419.

63 Letter 6 to Theoctista, Fatouros, vol. 1, pp. 21-22. 
And when Theoctista finally died, it was the idea of the predetermined council of God appointing the end of the human life that gave Theodore consolation. He begins the Funeral Oration in Honor of his Mother by stating that she departed from life "according to the determined council of God the Creator

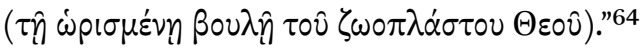

Yet acceptance or denial of predetermination in Byzantium was not a clearcut division; there is evidence that some accepted partial predetermination for those who died of "natural" causes, while rejecting predetermination for those who, in the words of one of the interlocutors of Patriarch Germanus' dialogue on predetermination, died from "foul play or some constraint of external circumstances." ${ }^{\prime 5}$ It is very likely that the theological and poetical drive of Theodore's canon on the deceased was precisely aimed at strengthening the theology of the fixed end of life and disproving those who did not believe in predetermination or believed that the fixed end of life only applied to those who died of natural causes.

However, for fostering this belief in his community, Theodore did not write an apologetic treatise on the subject, but preferred the form of a canon. Of course, it would be too bold to claim that we may know his precise reasons for that. However, it is likely that he wanted not to convince his brethren of a doctrinal belief by logical reasoning, which was the case with anti-Iconoclastic arguments in his homilies - there was a doctrine established by the Council of Nicaea II, which only had to be reminded of in a concise and logical form to those susceptible to Iconoclastic propaganda or given as a form of effective argumentative weapon for convincing others. What Theodore might have wanted to do is much deeper - to share with his monastic community his proven spiritually beneficial conviction derived from personal experience, both of the foretaste of Easter in the middle of hardships of the Great Lent, which, however, would never happen without the Cross, and of the loving care of God over individual human life in all difficult and sometimes even fatal circumstances, which has proven to be beneficial for the whole Eastern Church praying with Theodore's words until this day.

$64 \quad P G 99,884$ A.

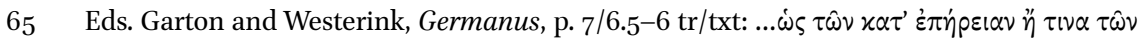

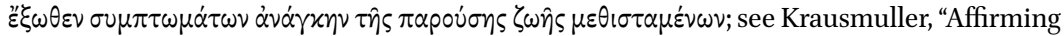
Divine Providence," pp. 396-398. On the discussion of "untimely death" in biblical and pseudoepigraphic writings, see J. W. Ludlow, "Untimely Death: Is There a Good Time to Die?" in: "To Recover What Has Been Lost": Essays on Eschatology, Intertextuality, and Reception History in Honor of Dale C. Allison Jr. eds. T. Ferda, D. Frayer-Griggs, and N. C. Johnson (Novum Testamentum, Supplements, 183), Leiden, 2020, pp. 142-157. 